\title{
Improving of informative and operating system of the power industry of food enterprises based on intellectualization the process of the decision making
}

\author{
Alina Siryk, Olga Yevtushenko
}

National University of Food Technologies, Kyiv, Ukraine

Keywords:

Labor

Intellectualization

Safety

Power

Article history:

Received

24.04.2018

Received in revised form 02.05.2018

Accepted

29.06.2018

\section{Corresponding}

author:

Alina Siryk

E-mail:

alsok3030@

gmail.com

DOI:

$10.24263 / 2310$

1008-2018-6-1-16

\section{Abstract}

Introduction. The improving of information and management system of the modern power enterprises of the food industry through the introduction of multiagent technologies that will allow to leader of power enterprise effectively use different sets of events within the total set of legal documents to improve the level of safety of labor.

Materials and methods. The research was conducted based on general system approach, grounded on interconnection of elements intelligent agent, information object, method of mathematical modeling.

Results and discussion. The process of intellectualization is proposed carry out based on introduction of multi-agent technologies that will allow to the leader of power enterprises effectively use different sets of events within the overall set of legal and regulatory documents to increase the level the safety of work. In addition, the increased efficiency of functioning the information and operating system of management the safety of work in the food industry, to allow determine the optimal set of events for labor safety, and this makes it possible to achieve improving the labor safety. It is showing the curtailment of time on solve the tasks of management the level of labor safety in a changing information environment, especially during the peak of load in the energy sector of the food industry. The results of mathematical modeling which based on using of multi-agent technologies in information and operating system of management the labor safety achieved improving labor safety in the energy sector of the food industry on $12-18 \%$.

Conclusion. The main research results are recommended for use on enterprises of the food industry to reduce the risk of an offensive extraordinary situation in the energy industry of food enterprises industry to a level that meets acceptable risk, at the expense of choice the optimal set of measures for ensuring labor safety. 


\section{Introduction}

In modern conditions of market business in Ukraine creating, reconstructing and operating a large number of enterprises of food industry that operate industrial power installs. Among the objects that operated, occupy a significant amount those installs, that were built and began to work in the last century with the consideration of requirements and technologies of that time. This is one of the factors that degrade the state of labor protection on enterprises.

Analysis of the modern economic situation in the food industry, including the energy sector, allow to make a conclusion about the presence of a crisis, primarily due to the presence of the investment deficit is practically blocked the process of renewal of the primary funds. The result of this is the abrupt fall of technological, production, labor discipline, which in turn significantly effect on the level of the safety of work.

Production in the food industry associated with the consumption of large amounts of electricity, fuel and other energy (steam, compressed air, hot water) and providing of communication systems. In the food industry the part of consumed energy in the production cost is about $30 \%$. Normal functioning of industrial system of the enterprise depends on timely supply of energy resources by their types and in a certain amount.

At the enterprises of food industry, a large number of factors that are interconnected and conditionality effect on the level of injury. Therefore, organizational structure of the providing the labor protection should be enough to prompt and consider all production factors, timely detection, do accounting of their, analysis and estimation and shut out traumatic situations. However, the system of energy sector is to expanded. Therefore, timely communication between the leader and departments is rather difficult.

In the modern conditions of business, that characterized by an extremely difficult situation in the country, the question of safety of the production processes in the field of labor protection take on particular topicality as in the conditions of a low funding it promotes the searching and rational use the ways of decrease the level of production injuries. Great contribution to the solution of these problems made domestic and foreign scientists: O.I. Amosha, R. Anderson, P. V. Beresnyevych, B.O. Bilinsky, Y.F. Bulgakov, G. Vylde, A.O. Vodyanyk, A.R.Hale, V. A. Glyva, H.H.Gogytashvili, V.I. Holinko, A.O. Gurin, O.I. Zaporozhets, W. Kelen, F.S. Klebanov, V.I. Kozlov, O. E. Kruzhylko, O.E. Lapshyn, O.G. Levchenko, G.V. Lesenko, M.O. Lysyuk, I.A. Luchko, N.A. Prahovnik, I. M. Podobed, A. Rayf, N.V. Stupnytska, K.N. Tkachuk, A.M. Feber, M.I. Shvydkyi. In particular, in [1] proposed a new system of the creation documentations for management systems of information security, that display features, that characteristic the system of management of information safety of the organization. In [2] improved the evaluating of effectiveness of management decisions under conditions of operation information-analytical systems based on uses the indicators of executive discipline, quality and effectiveness of realization of management decisions. The problems of perfection the system of management by labor protection on enterprises explored in the works of such authors as Shulga Y.I. Sukach S.V. [3], G.G. Gogitashvili G.G. [4], Lesenko G.G. [5], Sergienko M.I. [6], Romanchuk A.A. [7].

However, in the presents of a large number of scientific sources that consider the questions of the organization of safety and prevention injury in various industries today all these events are planning and implementing based on subjective opinion of leader considering on the economic opportunities (not decrease profits) and considering requirements of the regulatory framework. Considering the state of labor protection [8] carried out on the results of the consequences of injuries $[9,10]$ and occupational diseases of workers. In the background stays the task of neutralization the dangerous and harmful factors. 


\section{- Life Safety —}

One of the promising areas of research is the introduction of intellectualization of the process the decisions making based on the total amount of information. Only such decisions allow to produce the optimal set of events to providing the labor protection.

The process of improving the functioning the system of management the labor protection (SMLP) requires the rational organization and a coherent interaction between the leader of power manage and heads of all structural units, and effective interaction with industry, accordingly to state agencies and the implementation of all regulations.

Today on the forefront of science researches put the task of raising the level of intelligence of specialized control systems, which stems from the limitations of traditional informational approach. Within the general concept of construction, the information and management system of the power enterprise of food industry formulated agent-oriented approach to intellectual interaction of components.

Intelligent Agent (IA) - a program or hardware object that operates autonomously to achieve the aims set in front of it by the owner or the user that has certain intellectual abilities.

\section{Materials and methods}

Despite of number important works $[8,9,10]$ in the field of building integrated intellectual systems, the task of creating methods of designing intellectual information and management systems for such complex objects, the energy sector is not resolved. Require further research and development such questions as: the development object of the model of information and control system the energy sector of the food industry, which would include the base of a framework regulations in the field of safety of work; build a model intelligent agent for information and control system the energy sector of the food industry; build a model of finding a solution on the selection of total events [11] to raise the level of safety of the work in the energy sector of the food industry. Development of the methods for storage and search of regulatory and legal framework in the information and management system the energy sector of the food industry.

The mathematical model of the information object of intellectual information-analytical management system of the energy divisions for the food industry plants was developed that also includes an ability to update the database of labor laws.

The mathematical model of intellectual agent was created, as part of intellectual information-analytical management system of labor protection of the energy divisions for the food industry plants, which also includes parameters of harmful and dangerous factors of production flows.

In the work the topology and methodology of constructing an intellectual information and analytical system management of labor protection of the energy divisions for the food industry plants was developed and brought to practical implementation of architecture.

\section{Results and discussions}

In general, the model of information and control system the energy sector of the food industry can be represented as follows (Figure 1). 


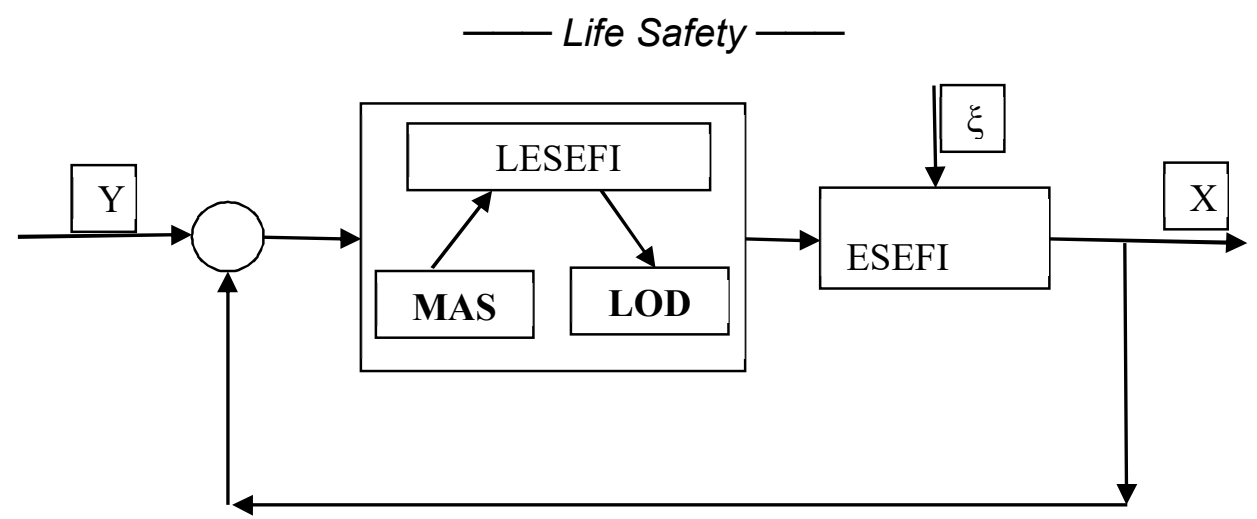

Figure 1. The general model of the information and control system the energy sector of the food industry:

$\mathrm{Y}$ - the vector of the regulatory and legal base; LESEFI -the leader of energy sector of the enterprises food industry; MAS - the multi-agent system; LOD - the leaders of official departments; $\xi$ - the destabilizing factors; $\mathrm{X}$ - the vector of the state the safety of work in the energy sector of food industry.

The task of rise the safety of work in the energy sector of the food industry using multiagent technologies in a formalized form it can be defined as

$$
\mathrm{L}(\mathrm{SW}) \rightarrow \operatorname{Max},
$$

where L(SW) - the level of the safety of work in the energy sector of the food industry, the imposition of limitation on value of the events

$$
\mathrm{C} \leq \mathrm{C}_{\mathrm{h}}
$$

An essential basis for formalization intelligent components of the information and control systems the energy sector, shown in Figure 1, is a model of information object (IO)

Information object propose to define as follows:

$$
\mathrm{O}:=<\mathrm{N}_{\mathrm{O}},\{\mathrm{A}\},\{\mathrm{O}\},\{\mathrm{F}\},\{\mathrm{L}\}>
$$

where $\mathrm{N}_{\mathrm{O}}$ - the name of object; $\{A\}$ - the set of object attributes $\left(A_{0}, \ldots, A_{n}\right), \mathrm{A}_{\mathrm{i}}-\mathrm{i}$-th attribute $\mathrm{IO} ;\{O\}-$ the set of objects, which structurally include in the object,

$\left(O_{N_{1}}, O_{N_{2}}, \ldots, O_{N O_{m}}\right)$, де $O_{N_{i}}$ i-th subordinated object, the object with name $\mathrm{N}_{\mathrm{O}} ;\{\mathrm{F}\}-$ set of functions which implement this IO, $\{\mathrm{L}\}$-the set of regulations, from which select the optimum set of recommendations.

The attribute of IO defined as:

$$
\boldsymbol{A}=\left\langle\boldsymbol{N}_{A}, \mathrm{~S}_{\mathrm{A}}, \mathrm{V}_{\mathrm{A}}>\right.
$$

where $\mathrm{N}_{\mathrm{A}}$ - the name of attribute, $\mathrm{S}_{\mathrm{A}}$ - the set, in which define the meaning of attribute, $\mathrm{V}_{\mathrm{A}}$ - the meaning of attribute, namely $\alpha \in \mathrm{S}_{\mathrm{A}}$ at this time $\mathrm{t}$.

Based on analysis of the characteristics and imperfections of the known models of intelligent agents (IA) IA proposes that the structure of IA look like: 


\section{Life Safety —$$
\mathrm{IA}=<\mathrm{N}_{\mathrm{IA}}, \mathrm{S}_{\mathrm{A}}, \mathrm{V}_{\mathrm{IA}}, \mathrm{M}_{\mathrm{VB}}, \mathrm{V}_{\mathrm{O}}>\text {, }
$$

where, $\mathrm{N}_{\mathrm{IA}}$-the name of intelligent agent; $\mathrm{S}_{\mathrm{A}}$-the structure of attributes, which defined similar to structure of attributes for information objects (IO); $\mathrm{V}_{\mathrm{IA}}=\{\mathrm{IA}\}-$ the sets of invested IA; $\mathrm{M}_{\mathrm{VB}}$-the mechanism of choice the model of operation the regulatory and legal base $\mathrm{VO}=\{\mathrm{O}\}-$ the set of information objects that implement the screenplays of work the IA.

The intelligent agent based on criterions the choice of model the functioning, founded in the $\mathrm{M}_{\mathrm{VB}}$, make a decision about the realization at this time some of the screenplay of work and initializes the appropriate IO. The information space of intelligent agent is defined as a set of IO and IA that surround $\mathrm{IA}_{\mathrm{i}}$ and interact with it, where

$$
\begin{aligned}
& A R_{I A}^{i}=\left(N_{I A j}, A_{I A_{j}}^{\xi}, \ldots, A_{I A_{j}}^{\psi}, N_{I A I}, A_{I A_{l}}^{\xi}, \ldots, A_{I A_{l}}^{\psi}\right), \\
& A R_{I O}^{i}=\left(N_{I O j}, A_{I O_{j}}^{\xi}, \ldots, A_{I O_{j}}^{\psi}, N_{I O I}, A_{I O_{I}}^{\xi}, \ldots, A_{I O_{I}}^{\psi}\right) .
\end{aligned}
$$

The model of choice the behavior of AI may be present: $\mathrm{M}_{\mathrm{VB}}=(\mathrm{MIS}, \mathrm{MG}, \mathrm{MSR}, \mathrm{MA})$, where MIS - the model of information environment, MG - the model of defining the aim, MSR - model of finding a solution considering the regulatory and legal framework, MA the model of active action.

The model of defining the aim is constructed so:

$$
M G_{I A_{i}}=\left(S S_{I A_{i}}, F S S_{I A_{i}}, G S_{I A_{i}}, G_{I A_{i}}^{\text {top }}, G_{I A_{i}}^{\text {down }}, F G_{I A_{i}}^{D}, F G_{I A_{i}}^{S}, F A G_{I A_{i}}, S M A_{I A_{i}}(t)\right) .
$$

Here SS - the set of strategies, that understand as methods for selecting aims $S S=\left(S_{i} \mid i=1, \ldots, n\right), \mathrm{FSS}$ - the function of choice the strategy; GS - the set of static aims, . $G^{\text {top }}$. -the set aims that get from this IA from agents a higher level of hierarchy, $G^{\text {down }}$ - the set of the aims that can be transferred to IA of lower levels; $F G^{D}$ - the function of forming the dynamic aims $F G^{S}$ - the function of choice the static aims; FAG -the function of choice the active aims, scilicet aims that accept to realization; SMA - the state of the multi-agent environment.

Under the search decisions should understand the finding of way to achieving the aim or aims given from IA in the current state of MA-environment (Figure2). Because different structural departments of the energy sector of the food industry has its own specific including at making a decision, it is hardly possible to use some universal method of searching a decision for all subsystems of IOS. 


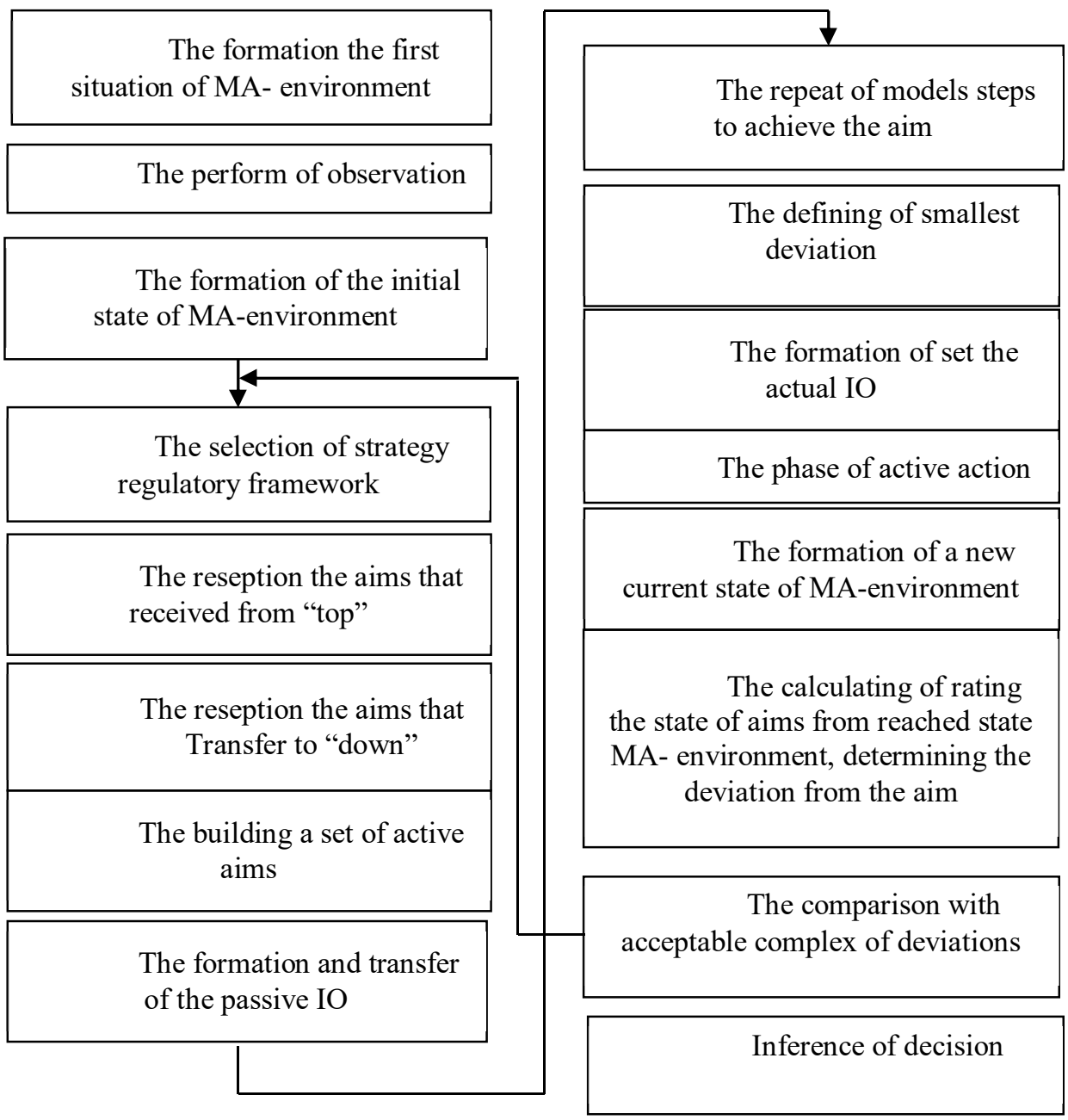

Figure 2. Algorithm for finding a solution by intelligent agent

In the proposed model IA, the following type of search solution. We think that the IA has a certain set of static aims $G S=\left\{g s^{i} \mid i=1, \ldots, n\right\}$. Here each IO cover some plan. Known ways to achieve the aims scilicet are built information objects . $\left(I O^{i} \mid i=1, \ldots, n\right)$, the operation of which should lead to $g s^{i}$. Here each IO cover some plan. Inside this plan, that is in behavior IO, can be formed arbitrary messages and arbitrary sequences of actions.

Then the model of finding a solution given the function of finding a solution $S R: G S \rightarrow V O$, where $\mathrm{VO}$ - a set of invested IO of i-th IA. This image is synonymous, but not mutually, because maybe, that some aims are achieved by the same IO. The model of active actions determined by image $A D: G A \rightarrow V O$, which chose necessary for launching in the current time of IO. 
The constructed model of finding a solution in a model of IA allows to describe such known classes models of realization behavior as a model with conditioned ending set of elementary actions; model with the set of plans; model with random messages and actions. On the base of this model can be created the new models of behavior the IA, that combine the mechanisms of different classes.

Based on designed methodology of searching a solution about the choice of totality of events to increase the level of safety the work [14], implemented the estimation of using of IOS on the example of the work the leader of the energy sector of the food industry.

The evaluation of the efficiency of work the information and management systems of energy sector the enterprises of the food industry considered on the example of the analysis of the algorithm of the head's activity of the energy sector in relation to the task of selecting the totality of events to increase the safety of work. The essence of the task is consist in choice the optimal set of tools to increase the level of the safety of work. For this task were divided into elementary operations (total 12 operations) and logical terms (3 conditions). Quantitative

characteristics (number of detected violations from safety of work per year, the number of staff's injuries per year, the number of days of sick leaves per year, the time of basic operation, time dispersion of basic operation and the probability of error-free implementation) are taken from statistical data $[12,13]$.

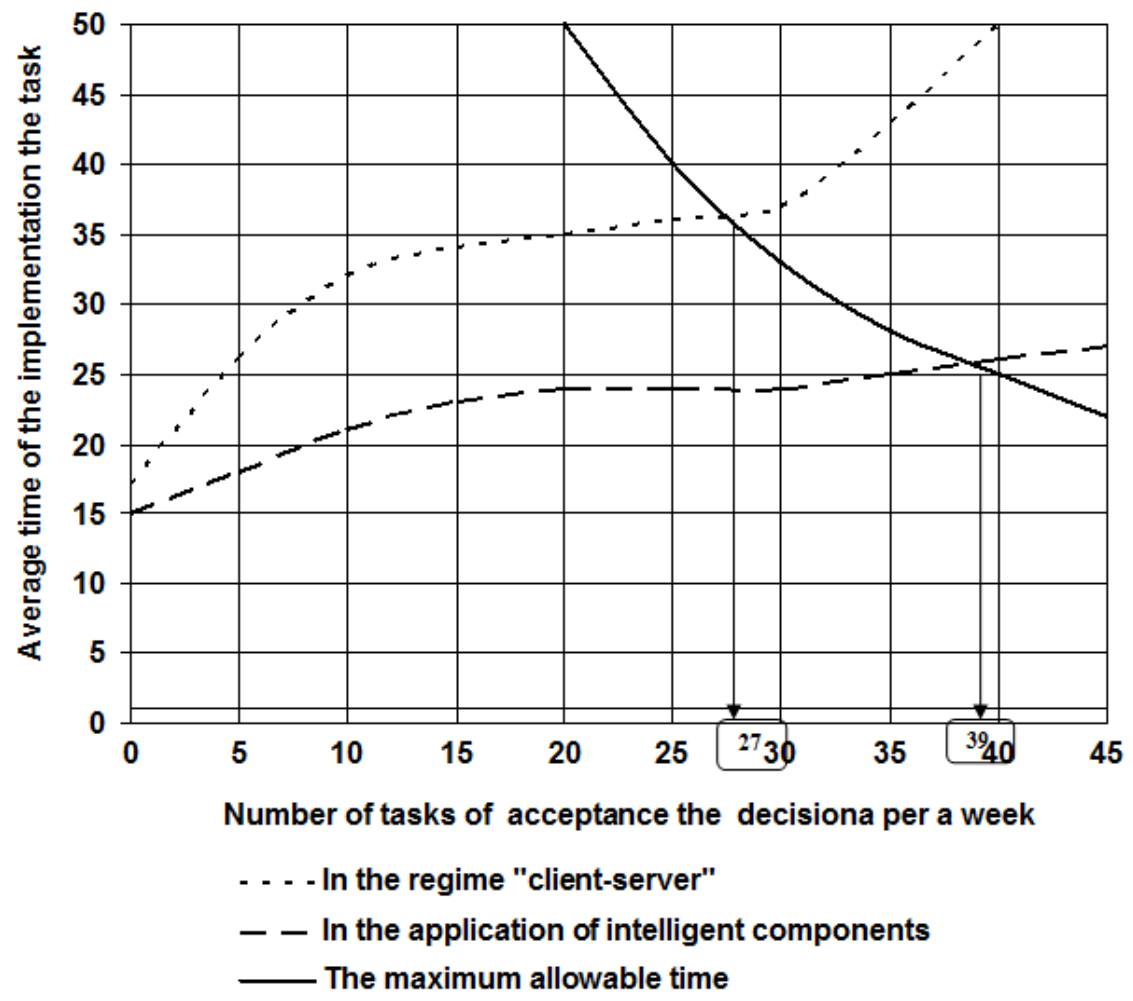

Figure 3. The dependence of the average time to make a decision from the number of tasks decision-making tasks per week 
On the graph (Figure 3) shows the average time for decisions by leader of the energy sector based on around-the-clock character of activity providing staff. As can be seen from the graphs, using intellectual IOS gives a essential advantage in solution the tasks of the choice the set of events to increase the level the safety of work, however, due that the average time on perform one solution in intellectualization system is less, the total number of decisions per week increases.

Solving the converse task about to definition the probability of faultless decisionmaking at a fixed time to solve management problems can also determine the effectiveness and feasibility of the introduction of intellectualization of information and operating system of the energy sector of the food industry. Thus, the rise of efficiency when using the same initial data will be $12-18 \%$.

\section{Conclusions}

In this work it is shown as possible to improve the information and operating system of the modern energy enterprises of the food industry by intellectualization of the process of the decision-making based on the received amount of information. This process of intellectualization is proposed carry out based on introduction of multi-agent technologies that will allow to the leader of power enterprises effectively use different sets of events within the overall set of legal and regulatory documents to increase the level the safety of work. In addition, the increased efficiency of functioning the information and operating system of management the safety of work in the food industry, to allow determine the optimal set of events for labor safety, and this makes it possible to achieve improving the labor safety. It is showing the curtailment of time on solve the tasks of management the level of labor safety in a changing information environment, especially during the peak of load in the energy sector of the food industry. The results of mathematical modeling which based on using of multi-agent technologies in information and operating system of management the labor safety achieved improving labor safety in the energy sector of the food industry on $12-18 \%$.

\section{References}

1. Kozhedub Yu.V. (2015), Stvorennia dokumentatsii dlia system upravlinnia informatsiinoiu bezpekoiu, Information Technology and Security, 3(5), pp. 95-100.

2. Kruzhylko O.Ye., Maistrenko V.V., Demchuk H.V. (2015), Otsinka efektyvnosti upravlinskykh rishen u sferi okhorony pratsi, Problemy okhorony pratsi v Ukraini, 29, pp. 3-9.

3. Shulha Yu.I., Sukach S.V., Kobylianskyi M.A., Velychko O.L., Mozghovoi O.V. (2012), Avtomatyzovanyi kontrol system bezpeky pratsi ta zhyttiezabezpechennia, Problemy okhorony pratsi v Ukraini, 22, pp. 16-26.

4. Hohitashvili H.H. (2002), Systemy upravlinnia okhoronoiu pratsi, Afisha, p. 320.

5. Lesenko H.H. (2003), Rozrobka ta vprovadzhennia SUOP na pidpryiemstvi, Okhorona pratsi, 6, pp. 36-38.

6. Serhiienko M.I., Bakhtina Ye.A. (2012), Pidvyshchennia okhorony pratsi tkatskoho vyrobnytstva za rakhunok vprovadzhennia novykh system kondytsiiuvannia zi zvolozhenym povitriam, Problemy okhorony pratsi v Ukraini, 23, pp. 109-115.

7. Romanchuk A.A. (2010), Sistemnyi menedzhment okhrany truda na predpriiatii. Modeli upravleniia. Chast 1., Ilichevsk. 


\section{- Life Safety -}

8. Kruzhilko Oleg, Bogdanova Olga (2016), Method of human factor minimization in expert judgement for occupational risk assessment and decision making, Ukrainian Journal of Food Science, 4(1), pp. 138-150.

9. Volodchenkova Nataliya, Hivrich Olexandr, Labzhynska Marharyta (2016), Evaluation of the working items of hotel-restaurant complex stability structures, Ukrainian Journal of Food Science, 4(1), pp. 151-158.

10. Kruzhylko O.Ye., Bohdanova O.V. (2016), Alhorytm pidhotovky upravlinskykh rishen na osnovi kombinovanoho metodu otsinky ryzyku vyrobnychoho travmatyzmu, Naukovi pratsi Natsionalnoho universytetu kharchovykh tekhnolohii, 3(22), pp.140149.

11. Horlova T.M. (2017), Pryiniattia upravlinskykh rishen u korporatyvnykh systemakh, Naukovi pratsi Natsionalnoho universytetu kharchovykh tekhnolohii, 23(2), pp.16-22.

12. Karmazina O.O. (2016), Statystychnyi biuleten. Travmatyzm na vyrobnytstvi u 2015 rotsi, Derzhkomstat Ukrainy, p. 124.

13. Karmazina O.O. (2015), Statystychnyi biuleten. Travmatyzm na vyrobnytstvi u 2014 rotsi, Derzhkomstat Ukrainy, p. 123.

14. Anderson W. E. (2005), Risk Analysis Methodology Applied to Industrial Machine Development. Industry Applications, IEEE Transactions on, 41(1), pp. 180-187. 